\title{
Have Labor Costs Slowed the Recovery?
}

\author{
B. Ravikumar, Vice President and Deputy Director of Research \\ Lin Shao, Washington University in St. Louis
}

M

any pundits in the media claim that labor market regulations, such as the Affordable Care Act and the increase in the minimum wage, have slowed the recovery from the 2007-09 recession (see, for example, Roy, 2014, and McNickle, 2014). The claim is that recent labor market regulations have increased labor costs and, as a result, employers have been reluctant to hire workers, leading to a slow labor market recovery.

In this essay, we compare labor costs after the 2007-09 recession with labor costs after the 2001 recession and also with the long-run trend. We use aggregate data and document employer costs using (i) labor cost per hour and (ii) labor cost per employed person. We measure the former as real total labor compensation divided by total hours worked and the latter as real total labor compensation divided by the total number of employed persons.

According to the National Bureau of Economic Research, recovery from the 2001 recession started in 2001:Q4 and from the 2007-09 recession started in 2009:Q2. Panel A of Figure 1 plots the labor cost per hour for the U.S. nonfarm business sector for both recoveries for 20 quarters. ${ }^{1}$ After the 2001 recession, labor cost per hour rose approximately 5 percent but after the 2007-09 recession remained essentially flat.

As shown in Panel B of Figure 1, a similar pattern holds for labor cost per employed person: It also grew at a slower rate after the 2007-09 recession than after the 2001 recession.

\section{Labor costs after 2009 grew more slowly than labor costs after 2001.}

The growth in labor costs was also less after the 2007-09 recession than the long-run average. From 1990:Q1 to the beginning of the 2007-09 recession, labor cost per hour grew an average 1.52 percent per year and labor cost per employed person grew an average 1.22 percent per year. Since 2009:Q2, they have grown on average only 0.46 percent and 0.67 percent per year, respectively.
Figure 1

A. Labor Cost Per Hour

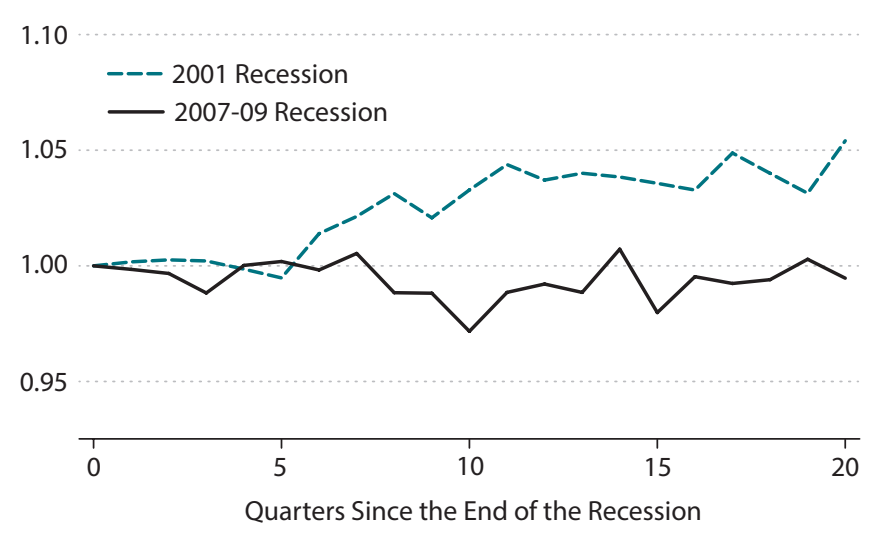

B. Labor Cost Per Person

1.10

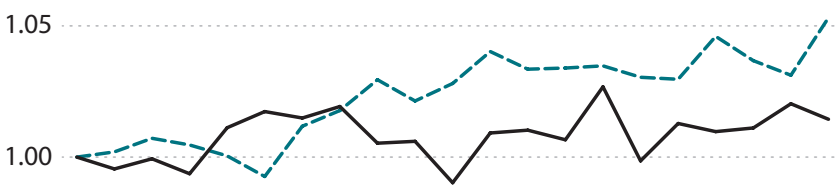

0.95

0

$\begin{array}{cccc}5 & 10 & 15 & 20 \\ \text { Quarters Since the End of the Recession } & \end{array}$

NOTE: Both lines are normalized to 1 at the start of the respective recoveries. Labor cost per hour equals real total labor compensation divided by total hours worked, and labor cost per employed person equals real total labor compensation divided by the total number of employed persons.

SOURCE: BLS Labor Productivity and Cost dataset for the nonfarm business sector.

Figure 2 shows total hours worked and total employed persons since 2001:Q4 and 2009:Q2. Both measures grew faster after the 2007-09 recession than after the 2001 recession. Total hours worked recovered particularly well: Twenty quarters into recovery, total hours worked were 8 percent higher after the 2007-09 recession but only 5 percent higher after the 2001 recession. 


\section{Figure 2}

\section{A. Total Hours}

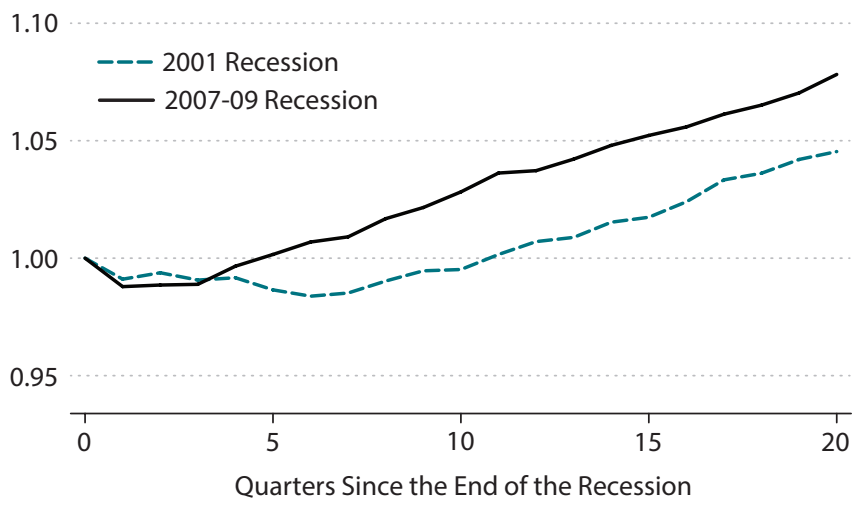

\section{B. Total Employed Persons}

1.10

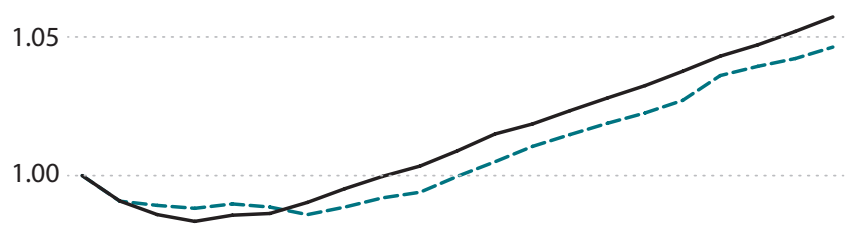

0.95

\begin{tabular}{ccccc}
\hline & 5 & 10 & 15 & 20 \\
& Quarters Since the End of the Recession &
\end{tabular}

NOTE: Both lines are normalized to 1 at the start of the respective recoveries. SOURCE: BLS Labor Productivity and Cost dataset for the nonfarm business sector.
In summary, the increase in labor costs during the recovery from the 2007-09 recession has been smaller than that from the 2001 recession. And, the increase in total hours worked and total employed persons has been larger during the recovery from the 2007-09 recession than from the 2001 recession. Hence, the aggregate data cast doubt on the proposition that an increase in labor costs due to labor market regulations has been the reason for the slow recovery from the 2007-09 recession.

\section{Note}

1 According to the Bureau of Labor Statistics (BLS), the nonfarm business sector is a subset of the domestic economy, excluding government, private households, and nonprofit organizations. Labor costs include wages and salaries, employer contributions for social insurance, and employer payments to employee benefit plans (including health and life insurance). See http://www.bls.gov/bls/glossary.htm for details.

\section{References}

McNickle, Colin. "Raise the Minimum Wage, Retard the Jobs Recovery." Triblive, May 10, 2014; http://triblive.com/opinion/colinmcnickle/604776574/wage-minimum-jobs\#axzz3otlOtPM5.

Roy, Avik. "Obamacare Is Dampening the Job Market in 3 Principal Ways." Forbes, September 1, 2014;

http://www.forbes.com/sites/theapothecary/2014/09/01/obamacare-isdampening-the-job-market-in-3-principal-ways/. 